\title{
Imo Edward's Adaptation of The Great Ponds by Elechi Amadi in Performance: A Review
}

\section{*Sunday EDUM}

\section{Introduction}

ñFor me this is a new experience. I never believed it is possible to achieve it. When I was told that they are to perform The Great Ponds, I asked myself, do this people know what they are saying? I now see why they award someone professor of theatre arts. I am impressed.o These were the words of the author of The Great Ponds, Capt. (Dr.) Elechi Amadi at the end of the premier of Imo Edwardôs adaptation of The Great Ponds from the prose to drama at the Hotel Presidential on 25th May, 2014.

Although, our business here is strictly on the performance as directed by Daniel Kpodoh, it is imperative that we acknowledge the author of the script who created the springboard for the performance: Mr. Edward Imo. He hails from Ahoada East Local Government Area of the Orashi region in Rivers State of Nigeria, holds a Bachelor of Arts Degree in Theatre Arts specializing in Playwriting, Master of Arts in Theatre Arts, specializing in Performance Theory and Criticism and is currently on the verge of completing his Ph.D in Theatre Theories and Criticism with emphasis on Stand-up Comedy at the University of Port Harcourt. He teaches Dramatic Theory and Criticism and Dramatic Literature in the Department of Theatre and Film Studies, University of Port Harcourt. Imo Edward is a budding scholar with an impressive number of published articles in both local and international journals.

Mr. Imo Edward in his new trade of adapting Elechi Amadiôs prose quickly reminds us of Kuroye Seiyefa who is regarded by some students of arts as an authority in the dynamics, form and content of Elechi Amadiôs literature. Mr. Imo Edwardôs pioneer effort in adapting The Concubine, one of Elechi Amadiôs

\footnotetext{
*Sunday EDUM of the Department of Theatre and Film Studies

University of Port Harcourt, Port Harcourt Email: edum2peace @ yahoo.com
} 
widely read proses with positive reception from members of the audience, may have encouraged his second adaptation journey of The Great Ponds by the same author (Elechi Amadi). Indeed, this adaptation effort has revealed the hidden possibilities in Elechi Amadiôs prose and championed a new performance mode for Amadiôs works. In Imo, therefore, one sees a Rotimi, Osofisan, Soyinka, Ogunyemi and Nwabueze who have experimented with the adaptation mode in Nigerian drama and theatre. One must not fail to encourage Imo to be bold and more creative in his adaptation mission like his predecessors. His fear of the original author appears to have reflected in his slavish approach of retaining the prose title in the two adaptations. His plotting of both works is so faithful to the original that one may feel the only creativity in his effort is the translation from prose to drama.

\begin{abstract}
About the Play
Anchored on the subjects of superstition, greed, communal clashes, megalomania and egocentricism, Imo Edwardôs adaptation of The Great Ponds is a physical and spiritual battle over the legitimate ownership of the pond of Wagaba. This battle of ownership results in kidnapping, war and oath-taking between the people Chiolu and Aliakoro, offspring of the ancient clan of Erekwi with women having a large share as victims. To lead the Chiolu in this battle is Olumba, the greatest warrior while Wago leads the Alikoro warriors in defence of motherland. After a series of battles without any group taking full control of the pond of Wagaba, Olumba swears in the shrine of Ogbunabali that the pond belongs to Chiolu. Both communities keep watch for six months to celebrate victory over the ownership of the pond of Wagaba. This celebration is determined by the death of Olumba as a result of the oath. Within the period of expected victory, sicknesses coincidentally afflict both communities. The incident is interpreted as the wrath of the gods. The play ends abruptly with Wago disguising as a masquerade to kill Olumba. His effort is unsuccessful and the light cuts off.
\end{abstract}


Meet the Director

Mr. Daniel Kpodoh holds a diploma in dance from the Obafemi Awolowo University, Ile-Ife, a professional certificate in directing and a Bachelor of Arts degree in theatre arts from the University of Port Harcourt. He is an artistic director, dancer, choreographer and dance instructor. His creative ingenuity is not in doubt as he is one of the mentees from the stable of Ojo Bakare popularly called Dancerasaki, who is one of the finest dance teachers Africa has ever produced. A man a leading creative director in Nigeria, Abdul Rasheed Adeoye, described as a ñconsultant multi-talented dance choreographer to over fifteen State Councils for Arts and Culture in Nigeriaò. Daniel Kpodoh has choreographed over ten dances and directed several plays such as The Trials by Julie Okoh, The Gardeners by Emmanuel Emasealu, Child Internationale by Wole Soyinka, Pepper Soup by Elechi Amadi and ñThe Scourge,ò a stage to script dramatization of the concept of discrimination on HIV/AIDS victims. His directorial strength was baptized when he produced and directed Ojo Bakareôs Drums of War with the dance drama approach within and outside Port Harcourt.

\section{Meet the Performance}

The production was a command performance produced by the Institute of Arts and Culture, University of Port Harcourt in collaboration with The Rainbow Book Club in celebration of the author of The Great Ponds, Chief Capt. (Dr.) Elechi Amadiôs 80 ${ }^{\text {th }}$ birthday. The performance parades the high and mighty made in óThe Crabô in the theatre profession. Amongst the experts are professors Julie Okoh as producer, Mr. Promise Uwuama as production manager, Boyle Adikiba as set designer, Patrick Agha as lighting technician and Nkechi Bature-Uzo as costumier. On the actors list we have Imo Edward as narrator, Princewill Emmanuel, Obina Idika, Monday as Olumba and Emeka Frankline Isioma as Wago and others whose names are unknown due to the lack of documentation in the form of production brochure from the producers.

óThe style makes the manôis a statement that is still valid in contemporary discourse. Daniel Kpodoh has created attention for 
himself with his unique style of ñdance dramatizationò. His interpretation of plays is usually dominated by dance drama approach irrespective of the style of the play. He borrows from Richard Wagner's theory of Artistic Synthesis which is akin to the African total theatre approach embellished with songs, drumming, dancing, acrobatics, acting and magic. As well, Daniel vies into Jerzy Grotowskyôs Biomechanics, Alienation and storytelling features of the ñEpic Theatreò of Betolt Brecht and Antoine Artaud ñTheatre of Crueltyò dominated with a sweetened to generate shock from the audience. In it, one may see a director masked with the euphoria of experimental theatre where major theatre conventional mistakes are justified.

As expected of Danielôs theatre, members of the audience were held spellbound in a dance drama performance with highly artistic movement, energy driven rhythm, collective participation mood, and acrobatic display by actors and culturally reflective songs, but with weak drumming for two hours. With mood, time of the day/period and illumination focused lighting supplied by the lighting teacher, Patrick Agha; character enhancing and culture situated costumes and poorly expressed makeup laced by Nkechi Bature-Uzor; symbolic and highly minimalist set probably conditioned by lack of funds deposited by Adikiba Boyle, Daniel Kpodohôs interpretation of Imo adaptation of The Great Ponds was entertaining and will remain memorable in the minds of the audience for a long time. The audience were participatory and active with intermittent applauds of the magical display of movement and destruction of hand props by the imported Chinese warriors to the land of Ikwerre.

In casting, Daniel often relies on the table casting or what Emasealu in his study of Rotimiôs Theatre refers to as solicited casting (102). His casting for the adaptation of The Great Ponds is commendable even though we saw dry chest boys and rag-tag soldiers as warriors and began to wonder at what point in the history of Ikwerre that boys became warriors. His target for the characters of Eze Diali, Eze Okehilkechi and Olumba was skillful. However, the characters of Diali and Olumba appear to have been 
misinterpreted by the actors who played them. The character of Olumba who is presumably a typical Ikwerre warrior like the powerful Isiburu in Elechi Amadiố Isiburu was rather interpreted by the actor as a ònative doctorò with weak charms at some point and a modern day Niger Delta militant at other points. His unpardonable mistakes of muddling lines and poor diction notwithstanding, he must be encouraged with inestimable thanks for fitting into the directorô theatre of entertainment and carrying the role of Olumba from the beginning to the end. The character of Eze Diali on the other hand still lives in the minds of the audience after the performance because of the actor's unique interpretation style. Although, his expressed traits of the character domesticate the character to be vicious and wicked, whereas, the character demonstrated qualities of a peacemaker. This is evident in the second light-on when he moderated the meeting between his people (Chiolu) and Aliakoro. He insisted that the Aliakoro people be allowed to pay a lesser fee as against the exorbitant fee of 800 manilas. He also demonstrated love for the Aliakoro people when he advised his kinsmen to shield their sword in their attempt to fight in his supposed palace. His offering of kola to the Aliakoro people when they visited is another testimony of his peaceful disposition. One can also recall his position that the dibia should protect Olumba from the hands of Wago and Okehi during the oath.

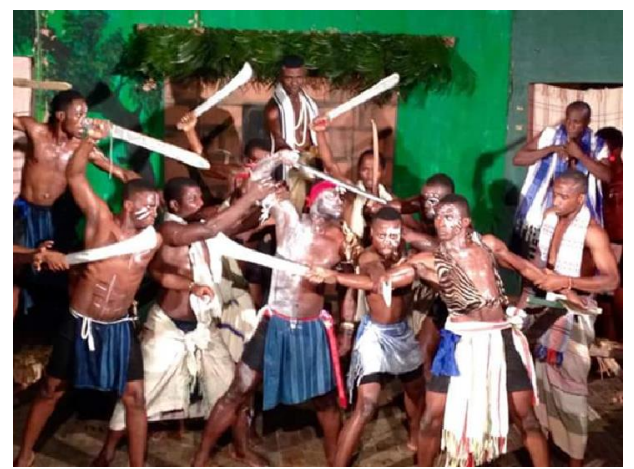

Warriors of Aliakoro and Chiolu in a battle (This reveal Daniel Kpodoh's use of Picturization) 
Another issue that deserves attention is the genre of the performance. Many of the theatre critics who witnessed the performance as well as those who are familiar with the prose which the work was adapted from were quick to express dissatisfaction with the disappearance of the tragic spirit in the work. An issue as serious as communal clash characterized with deaths, bbloodshed, rape and oath-taking may be mere entertainment if interpreted outside the tragic vision of any kind. Could this be a deliberate attempt to murder tragedy in disguise of the experimental? Issues of life and death were dramatized comically and the audience who were supposed to ponder over the issues raised were rather engrossed in laughter without recourse to the message of the play. This genre misinterpretation climaxed when the Narrator came in to muscle the audience into accepting theatre of the absurd as the genre. This was rather strange to some of us who are familiar with theatre of the absurd, which is an unconscious movement that emanated as a result of the First and Second World Wars to express the meaninglessness of life was absolutely far from what occurred on stage. However, the director and the entire company deserve some pat in the back for sustaining the tempo of the performance in entertaining the audience.

\section{Conclusion}

Staging a production in this part of the world has been characterized by numerous challenges which include poor funding, short time notice, lack of professional hands, poor audience attendance and above all poor remuneration for the performing artists. In a chat with the director Mr. Daniel Kpodoh, he lamented poor funding and lack of time for the production as some of the challenges he encountered in his interpretation. A command production of this magnitude with over six scenes, over thirty members of cast and crew was only rehearsed for less than two weeks with meagre amount as funding fee. This is not only frustrating on the side of the director but an abuse of theatre practice from the producers or executive producer(s). This abuse of theatre practice by the organizers is clear as the production lacks print documentation in the form of production brochure even when 
it is to celebrate a literary icon. Looking at the sponsors of the production gives one serious doubts on the value given to theatre. Rainbow Book Club whose cardinal objective is to promote literature and the Institute of Arts and Culture whose core values include reviving theatre practice in Nigeria displayed failure in practising what they preach. As we collectively champion a new course in theatre practice, we pray to see a performance properly rehearsed for a minimum of thirty days with enough funds provided to cover production materials, remuneration of cast, adequate welfare for artiste and respect for creativity by members of the audience. This will definitely improve on the performance delivery and reduce fire brigade approach to rehearsals whose outcome is a hospital bed rather than a vacation trip.

\section{Works Cited}

Amadi, Elechi. Great Ponds. London: Heinemann, 1969.

Edward, Imo. ñAn Adaptation of Great Ponds.ò Unpublished Drama Script, 2014.

Edum, Sunday, Oral Interview with Daniel Kpodoh, Artistic Director, Great Ponds, The Crab Arts Theatre, University of Port Harcourt, 2014.

Emasealu, Emmanuel. Theatre of Ola Rotimi : Production and Performance Dynamics. Minna: Gurara, 2010. 